\title{
A Novel Low Temperature Synthesis of KNN Nanoparticles by Facile Wet Chemical Method
}

\author{
Rashmi Rani1,2,3*, Seema Sharma1, Marzia Quaglio², Radheshyam Rai', Stefano Bianco33, \\ Diego Pugliese ${ }^{3}$, Candido Fabrizio Pirri ${ }^{2,3}$
}

\author{
${ }^{1}$ Ferroelectric Research Laboratory, Department of Physics, A. N. College, Patna, India \\ ${ }^{2}$ Center for Space Human Robotics (CSHR), Instituto Italiano di Tecnologia (IIT), Torino, Italy \\ ${ }^{3}$ Department of Applied Science and Technology (DISAT), Politecnico di Torino, Torino, Italy \\ ${ }^{4}$ School of Physics and Materials Science, Shoolini University, Solan, India \\ Email: *newton_rashmi51@yahoo.com
}

How to cite this paper: Rani, R., Sharma S., Quaglio, M., Rai, R., Bianco, S., Pugliese, D. and Pirri, C.F. (2017) A Novel Low Temperature Synthesis of KNN Nanoparticles by Facile Wet Chemical Method. Materials Sciences and Applications, 8, 247257.

https://doi.org/10.4236/msa.2017.83017

Received: January 4, 2017

Accepted: March 14, 2017

Published: March 17, 2017

Copyright (C) 2017 by authors and Scientific Research Publishing Inc. This work is licensed under the Creative Commons Attribution International License (CC BY 4.0).

http://creativecommons.org/licenses/by/4.0/

\begin{abstract}
Sodium potassium niobate (KNN) $\left(\mathrm{K}_{0.5} \mathrm{Na}_{0.5} \mathrm{NbO}_{3}\right)$ nanopowder with a mean particle size of about $20-30 \mathrm{~nm}$ was synthesized by wet chemical route using $\mathrm{Nb}_{2} \mathrm{O}_{5}$ as $\mathrm{Nb}$ source. A solution of $\mathrm{K}, \mathrm{Na}$ and $\mathrm{Nb}$ cations was prepared, which resulted in a clear gel after the thermal treatment. Phase analysis, microstructure and morphology of the powder were determined by $X$-ray Diffraction (XRD), Fourier Transform Infrared Spectroscopy (FTIR) and Field Emission Scanning Electron Microscopy (FESEM). The obtained gel was first analyzed by Thermo Gravimetric Analyzer (TGA) and Differential Scanning Calorimetry (DSC), and then calcined at different temperatures of $400^{\circ} \mathrm{C}, 500^{\circ} \mathrm{C}, 600^{\circ} \mathrm{C}$ and $700^{\circ} \mathrm{C}$. The $X$-Ray Diffraction (XRD) patterns of the synthesized samples confirmed the formation of the orthorhombic crystal phase of $\mathrm{K}_{0.5} \mathrm{Na}_{0.5} \mathrm{NbO}_{3}$ at $500^{\circ} \mathrm{C}$, a temperature significantly lower than that typically used in the conventional mixed oxide route. The process developed in this work is convenient to realize the mass production of KNN nanopowders at low cost and suitable for various industrial applications.
\end{abstract}

\section{Keywords}

KNN Nano-Powder, Sol-Gel Method, Perovskite Phase, Low Temperature Sintering, Ceramic Processing

\section{Introduction}

$\mathrm{K}_{0.5} \mathrm{Na}_{0.5} \mathrm{NbO}_{3}$ system, with $x=0.5 \mathrm{~mol} \%$, is a solid solution of ferroelectric $\mathrm{KNbO}_{3}$ and antiferroelectric $\mathrm{NaNbO}_{3}$ and is considered as one of the most promising classes of lead-free dielectric and piezoelectric materials because of its 
high Curie temperature and large electromechanical coupling factor [1].

Unfortunately, there are some issues in the preparation of highly densified $\mathrm{K}_{0.5} \mathrm{Na}_{0.5} \mathrm{NbO}_{3}$ ceramics, like the relatively high leakage current due to the volatilization of alkaline elements during the thermal treatment and the formation of lattice defects [2]. Many attempts have been made to obtain dense KNN ceramics by using doping methods as well as different synthesis processes [3] [4]. X. Vendrell et al. reported lanthanum doped KNN thin films characterized by a lower leakage current density at low electric fields, which should be favorable for the development of low leakage current films [5].

Usually, KNN polycrystalline powders are prepared by the conventional solid-state reaction (SSR) method using carbonates or oxides as starting materials. The particle size of these starting materials is in the micrometer or submicrometer range, and therefore a perovskite phase-forming minimum temperature of $850^{\circ} \mathrm{C}$ is needed so that the components of the mixture have sufficient thermal energy to overcome the atomic/ionic diffusion barriers for the reaction. It should also be noted that the high-temperature heating required in this method leads not only to remarkable energy consumption and high agglomeration, but is also responsible for the large particle size of the synthesized KNN powders.

In comparison, nanocrystalline powder provides an enhanced stored energy for solid state densification due to a higher inherent surface area, ultimately resulting in a lower sintering temperature and a higher densification [6] [7]. Additionally, a lower sintering temperature is also useful to reduce the loss of highly volatile potassium content in the KNN system.

The sol-gel method has been extensively used to prepare single-phase nanocrystalline powders of piezoelectric ceramics [8] [9]. In contrast with other techniques, the sol-gel process has shown considerable advantages, including excellent chemical stoichiometry, potential of homogeneous doping, easy scale-up to mass production and lower crystallization temperature due to the mixing of liquid precursors on the molecular level [10] [11].

Within this framework, in the present work a nanocrystalline $\mathrm{K}_{0.5} \mathrm{Na}_{0.5} \mathrm{NbO}_{3}$ ceramic was prepared by a sol-gel method involving carbonates of potassium and sodium and oxide of niobium $\left(\mathrm{Nb}_{2} \mathrm{O}_{5}\right)$. Usually, in sol-gel method niobium alkoxides $\left(\mathrm{C}_{n} \mathrm{H}_{2 n+1} \mathrm{O}\right)_{5} \mathrm{Nb}$ were used as $\mathrm{Nb}$ source of niobate materials, such as $\mathrm{K}(\mathrm{Ta}, \mathrm{Nb}) \mathrm{O}_{3}, \mathrm{LiNbO}_{3}$ and similar [12] [13]. Unfortunately, their high cost and easiness to hydrolysis made them difficult to be exploited in industrial applications. Here, the cheaper and widely available $\mathrm{Nb}_{2} \mathrm{O}_{5}$ was changed into a water-soluble species through the chemical chelation and was employed as the $\mathrm{Nb}$ source to produce $\mathrm{K}_{0.5} \mathrm{Na}_{0.5} \mathrm{NbO}_{3}$ nanocrystalline system.

\section{Materials and Methods}

\subsection{Material Synthesis}

$\mathrm{K}_{0.5} \mathrm{Na}_{0.5} \mathrm{NbO}_{3}$ nanocrystalline ceramic was prepared by a sol-gel reaction technique using niobium oxide $\left(\mathrm{Nb}_{2} \mathrm{O}_{5}, 99.9 \%\right.$, Sigma Aldrich chemicals, USA), 
potassium hydroxide ( $\mathrm{KOH}, 97 \%$, Sigma Aldrich chemicals, USA), sodium carbonate $\left(\mathrm{Na}_{2} \mathrm{CO}_{3}, 99.8 \%\right.$, Sigma Aldrich chemicals, USA), potassium carbonate $\left(\mathrm{K}_{2} \mathrm{CO}_{3}, 99 \%\right.$, Sigma Aldrich chemicals, USA), acetic acid $\left(\mathrm{CH}_{3} \mathrm{COOH}, 99.5 \%\right.$, Sigma Aldrich chemicals, USA), oxalic acid $\left((\mathrm{COOH})_{2} \cdot 2 \mathrm{H}_{2} \mathrm{O}, 99.5 \%\right.$, Sigma Aldrich chemicals, USA), citric acid $\left(\mathrm{C}_{6} \mathrm{H}_{8} \mathrm{O}_{7} \cdot \mathrm{H}_{2} \mathrm{O}, 99.5 \%\right.$, Sigma Aldrich chemicals, USA) and nitric acid $\left(\mathrm{HNO}_{3}, 65.0 \%\right.$ - 68.0\%, Sigma Aldrich chemicals, USA) [14].

In this experiment, $\mathrm{Nb}_{2} \mathrm{O}_{5}(0.48 \mathrm{~g})$ and $\mathrm{KOH}(1.22 \mathrm{~g})$ were firstly mixed and calcined at $350^{\circ} \mathrm{C}$ for $2 \mathrm{~h}$ to obtain a $\sim 2 \mathrm{~g}$ of soluble potassium niobate $\left(\mathrm{K}_{3} \mathrm{NbO}_{4}\right)$. The soluble potassium niobate $\left(\mathrm{K}_{3} \mathrm{NbO}_{4}\right)$ was subsequently solved into distilled water $(10 \mathrm{ml})$ and titrated by nitric acid (3 - 4 drops) to form a precipitate of niobium hydroxide $\left(\mathrm{Nb}(\mathrm{OH})_{5}\right)$. After washing several times to remove potassium ion, a soluble niobium precursor was gained in virtue of the freshly precipitated $\mathrm{Nb}(\mathrm{OH})_{5}(1.69 \mathrm{~g})$ chelated with oxalic acid (4.10 g), as shown in Figure 1(a). The niobium precursor solution was prepared by employing the following conditions: $2 \mathrm{~h}$, room temperature, $\mathrm{pH}$. The chemical reactions that took place can be written as follows:

$$
\begin{gathered}
\mathrm{Nb}_{2} \mathrm{O}_{5}+6 \mathrm{KOH} \rightarrow 2 \mathrm{~K}_{3} \mathrm{NbO}_{4}+3 \mathrm{H}_{2} \mathrm{O} \uparrow \\
6 \mathrm{~K}_{3} \mathrm{NbO}_{4}+5 \mathrm{H}_{2} \mathrm{O} \rightarrow 18 \mathrm{~K}^{+}+\mathrm{Nb}_{6} \mathrm{O}_{16}^{8-}+10 \mathrm{OH}^{-} \\
\mathrm{Nb}_{6} \mathrm{O}_{19}^{8-}+11 \mathrm{H}_{2} \mathrm{O}+8 \mathrm{H}^{+} \rightarrow 6 \mathrm{Nb}(\mathrm{OH})_{5} \downarrow \\
2 \mathrm{Nb}(\mathrm{OH})_{5}+5 \mathrm{HOOC}-\mathrm{COOH} \rightarrow 2 \mathrm{Nb}^{5+}+10 \mathrm{H}_{2} \mathrm{O}+5(\mathrm{COO})_{2}^{2-}
\end{gathered}
$$

According to the chemical stoichiometry of $\mathrm{K}_{0.5} \mathrm{Na}_{0.5} \mathrm{NbO}_{3}$, the as-prepared niobium precursor solution was mixed with $\mathrm{Na}_{2} \mathrm{CO}_{3}(0.96 \mathrm{~g})$ and $\mathrm{K}_{2} \mathrm{CO}_{3}(1.26 \mathrm{~g})$ into a diluted solution of citric acid (1.92 g), and subsequently acetic acid (2-3 drops) was added to control the $\mathrm{pH}$ value up to 4 . For obtaining a homogeneous sol, vigorous stirring for $2 \mathrm{~h}$ was required. Finally, the $\mathrm{K}_{0.5} \mathrm{Na}_{0.5} \mathrm{NbO}_{3}$ sol was heated at $80^{\circ} \mathrm{C}$ for $12 \mathrm{~h}$ to prepare dried gel and the dried gels were calcined at different temperatures from 400 up to $700^{\circ} \mathrm{C}$ for $4 \mathrm{~h}$ (see Figure $1(\mathrm{~b})$ ).

\subsection{Characterizations}

Thermo gravimetric and differential scanning calorimetry (DSC) analyses were
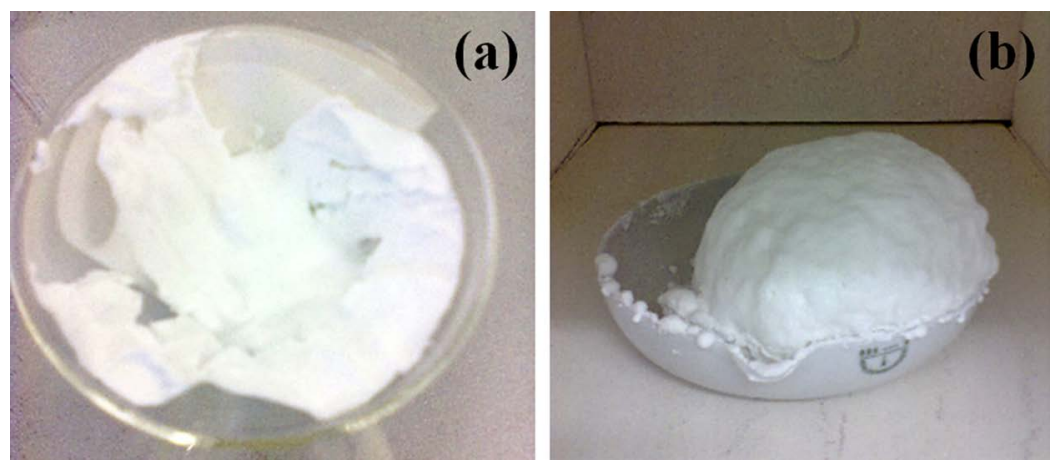

Figure 1. Photographs of $2 \mathrm{Nb}(\mathrm{OH})_{5}$ after washing with water (a) and $\mathrm{KNN}$ powder calcined at $600^{\circ} \mathrm{C}(\mathrm{b})$. 
performed using Netzsch TG 209 F1 TGA from room temperature up to $800^{\circ} \mathrm{C}$ under dry air. The heating rate was fixed at $10^{\circ} \mathrm{C} / \mathrm{min}$.

The crystalline structure of the sintered samples was examined using $X$-Ray Diffraction (XRD) analysis with $\mathrm{CuK}_{\alpha}(\lambda=1.5405 \AA)$ radiation in a wide range of Bragg angles $2 \theta\left(20^{\circ} \leq 2 \theta \leq 70^{\circ}\right)$ at a scanning rate of $2^{\circ} /$ min by Panalytical $X$ pert pro $X$-ray Diffractometer.

The microstructures were observed using the scanning electron microscope FESEM, Dual Beam Auriga from Carl Zeiss, at $5 \mathrm{keV}$.

FTIR spectra were obtained using Bruker, Tensor 27. Excitation was taken as the $488 \mathrm{~nm}$ line of $\mathrm{Ar}^{+}$laser with $100 \mathrm{~mW}$ output power. The samples for FTIR analysis were prepared by $\mathrm{KBr}$ pellet method.

\section{Results and Discussion}

\subsection{TGA/DSC Analysis}

The sol-gel synthesis of the $\mathrm{K}_{0.5} \mathrm{Na}_{0.5} \mathrm{NbO}_{3}$ samples from alkaline carbonates and niobium oxide was followed by thermal analysis (see Figure 2).

The overall weight loss was equal to $54 \%$ from room temperature up to $800^{\circ} \mathrm{C}$. The TGA curve shows an $18 \%$ weight loss between $25^{\circ} \mathrm{C}$ and $200^{\circ} \mathrm{C}$. In the same temperature range, the DSC curve shows two endothermic processes positioned at around $100^{\circ} \mathrm{C}$ and $200^{\circ} \mathrm{C}$, which are associated to the departure of water molecules during the thermal decomposition of the precursor (oxalato-niobium complex) [15]. The presence of water in the carbonate-oxide powder mixture is due to the hygroscopic nature of both carbonates, particularly $\mathrm{K}_{2} \mathrm{CO}_{3}$, which easily absorbs a few wt\% of water in normal atmosphere where the manipulation of the precursor powder takes place. The weight loss of $14 \%$ between $200^{\circ} \mathrm{C}$ and $300^{\circ} \mathrm{C}$ indicates an elimination of organic material.

The DSC analysis shows a corresponding endothermic peak at $300^{\circ} \mathrm{C}$. This endothermic process may be related to the release of water molecules, ammo-

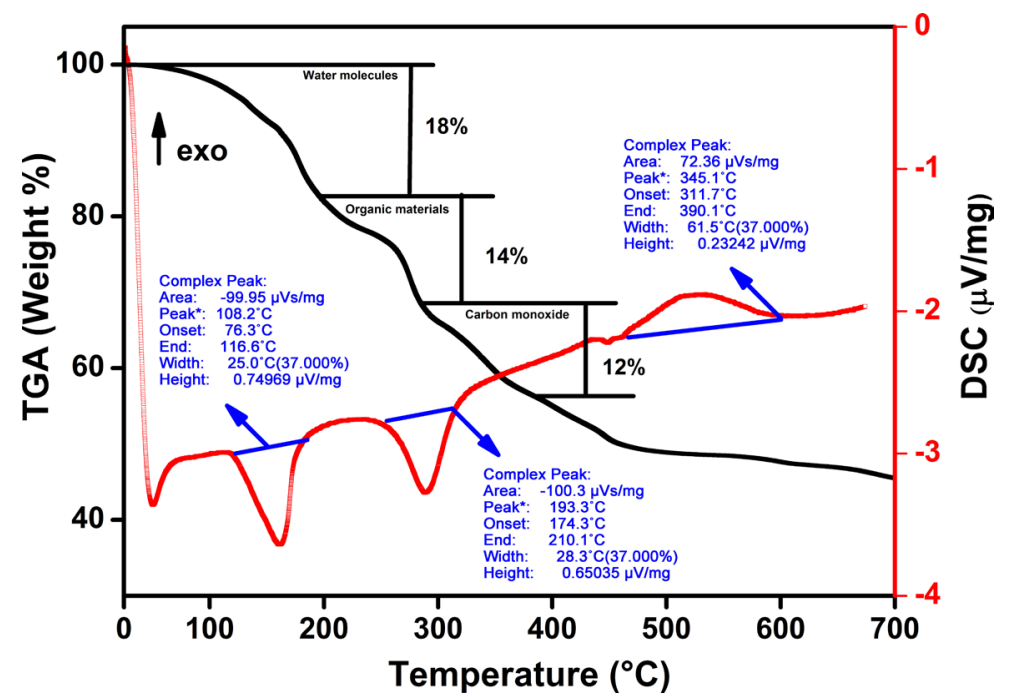

Figure 2. TGA and DSC curves of $\mathrm{K}_{0.5} \mathrm{Na}_{0.5} \mathrm{NbO}_{3}$ precursor powder acquired at a heating rate of $10^{\circ} \mathrm{C} / \mathrm{min}$. 
nium ions and $\mathrm{CO}$ and $\mathrm{CO}_{2}$ molecules developed by the combustion of organic ligands, which led to the formation of an intermediate oxalato-niobate complex.

Between $300^{\circ} \mathrm{C}$ and $400^{\circ} \mathrm{C}$, the TGA curve shows a weight loss of $\sim 10 \%$, which can be assigned to the elimination of $\mathrm{CO}$ from the mono (oxalato) complex decomposition. As a matter of fact, the thermal decomposition of simple or complex oxalates occurs with the formation of $\mathrm{CO}$ and $\mathrm{CO}_{2}$, which can remain in the intermediate phase, adsorbed on the surface of the solid products [16].

Exothermic crystallization of the sodium potassium niobate phase was observed at $400^{\circ} \mathrm{C}$ (Figure 2). No weight loss and no thermal effect were observed above $490^{\circ} \mathrm{C}$, indicating that no decomposition occurs above that temperature. Increased temperatures enhance the crystallinity of the calcined powder, as confirmed by the XRD analysis.

\subsection{X-Ray Diffraction Analysis at Different Temperatures}

Figure 3 shows the XRD patterns of the $\mathrm{K}_{0.5} \mathrm{Na}_{0.5} \mathrm{NbO}_{3}$ powders calcined at different temperatures. The sample heated at $400^{\circ} \mathrm{C}$ exhibits the formation of many impurities during the initial crystallization, maybe ascribable to the hydrated carbonate phases present in an amorphous form. When temperature increases above $500^{\circ} \mathrm{C}$, a small amount of secondary phase of $\mathrm{K}_{3} \mathrm{Nb}_{6} \mathrm{O}_{17}$ was observed in XRD.

As it can be seen at $600^{\circ} \mathrm{C}$, good agreement exists between the calculated and the observed diffraction profiles. Estimated values of the unit cell lattice parameters of $\mathrm{K}_{0.5} \mathrm{Na}_{0.5} \mathrm{NbO}_{3}$ powders calcined at $600^{\circ} \mathrm{C}$ were obtained using POWD software for the orthorhombic crystal structure and were found to be

$$
a=5.653 \AA, b=5.671 \AA, c=3.952 \AA
$$

These values have been compared with $a=5.695 \AA, b=5.721 \AA, c=3.974 \AA$, typical of a standard orthorhombic $\mathrm{K}_{0.5} \mathrm{Na}_{0.5} \mathrm{NbO}_{3}$ pattern (JCPDS, Joint Com-

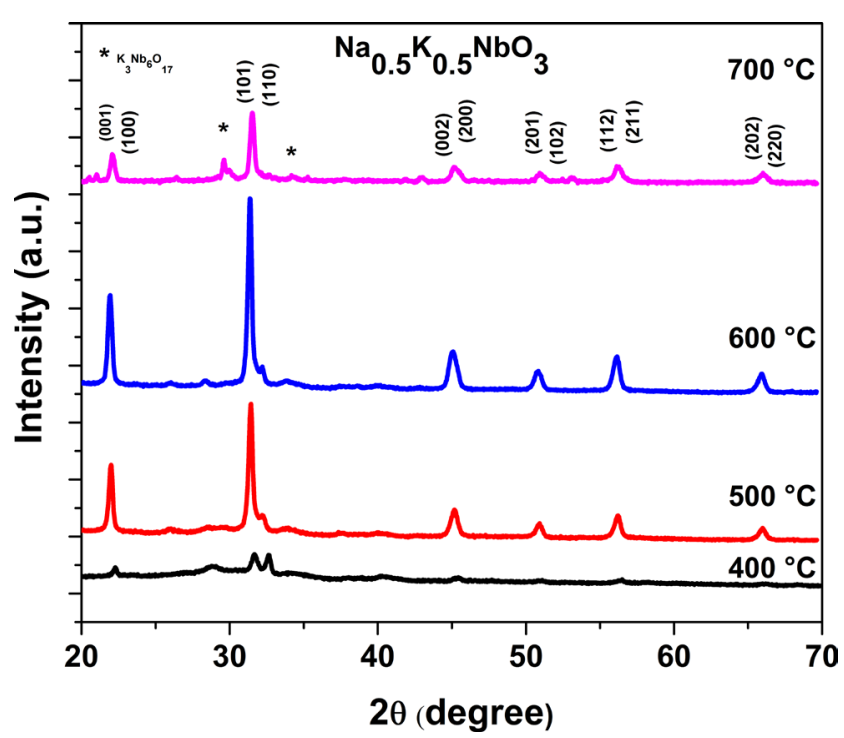

Figure 3. XRD patterns of the KNN dried gels calcined at various temperatures: $400^{\circ} \mathrm{C}$, $500^{\circ} \mathrm{C}, 600^{\circ} \mathrm{C}$ and $700^{\circ} \mathrm{C}$. 
mittee for Powder Diffraction file no. 32-0822). KNN average crystallite size was calculated by using Scherrer's equation [17]

$$
D=K \lambda / \beta_{2 \theta} \cos \theta,
$$

where $D$ is the mean grain size, $K=0.94$ is the Scherrer's constant related to the shape and the index (h.k.I) of the crystal, $\theta$ is the diffraction angle, $\lambda$ is the $X$-Ray wavelength used $\mathrm{CuK}_{\alpha}=1.5405 \AA$, and $\beta_{2 \theta}$ is the broadening of diffraction lines measured at half of their maximum intensity (in radian). The calculated mean crystallite size was estimated to be about $23.7 \mathrm{~nm}$.

\subsection{FESEM Investigation}

Figure 4 shows the FESEM images of $\mathrm{K}_{0.5} \mathrm{Na}_{0.5} \mathrm{NbO}_{3}$ powders annealed at four different temperatures. The temperature significantly affected the microstructure of $\mathrm{K}_{0.5} \mathrm{Na}_{0.5} \mathrm{NbO}_{3}$ ceramics, as shown in the four panels of the figure. At an annealing temperature of $400^{\circ} \mathrm{C}$ (Figure $4(\mathrm{a})$ ), the surface structure showed inhomogeneous and abnormal grain growth and intergranular porosity was detected due to voids between the nanoparticles.

Comparatively, the microstructure of $\mathrm{K}_{0.5} \mathrm{Na}_{0.5} \mathrm{NbO}_{3}$ powder calcined at $500^{\circ} \mathrm{C}$ (Figure 4(b)) was much more uniform and fine; the majority of the ultrafine particles showed a size less than $50 \mathrm{~nm}$ and were clustered into agglomerates, while some grains grew up to a size exceeding $200 \mathrm{~nm}$. The particle size was found to be about $20-30 \mathrm{~nm}$ for the samples calcined at $600^{\circ} \mathrm{C}$ (Figure $4(\mathrm{c})$ ), showing a good agreement with the particle size obtained from XRD line-broadening results. By raising the temperature up to $700^{\circ} \mathrm{C}$ (Figure $4(\mathrm{~d})$ ), the number of grains greater than $100 \mathrm{~nm}$ increased and the number of grains smaller than $25 \mathrm{~nm}$ decreased. The pores gradually disappeared as the sintering
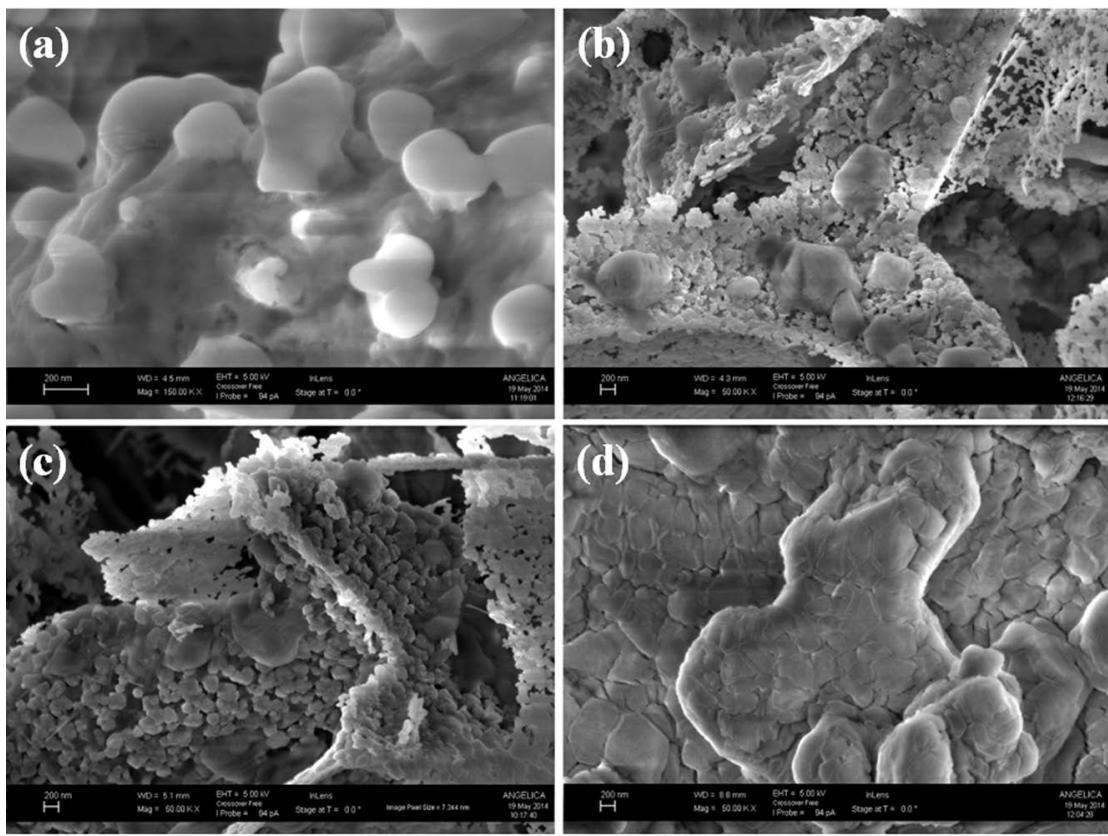

Figure 4. FESEM micrographs of the KNN ceramics annealed at different temperatures: (a) $400^{\circ} \mathrm{C}$, (b) $500^{\circ} \mathrm{C}$, (c) $600^{\circ} \mathrm{C}$ and (d) $700^{\circ} \mathrm{C}$. 
temperature increased, showing the involvement of a denser microstructure. However, above $700^{\circ} \mathrm{C}$ the $\mathrm{K}_{0.5} \mathrm{Na}_{0.5} \mathrm{NbO}_{3}$ nanopowder melted inhomogeneously and began to degrade.

\subsection{FTIR Analysis}

Figure 5 shows the FTIR spectrum of the pure $\mathrm{K}_{0.5} \mathrm{Na}_{0.5} \mathrm{NbO}_{3}$ ceramics annealed at $600^{\circ} \mathrm{C}$, in the frequency range $4000-400 \mathrm{~cm}^{-1}$.

In the low frequency region (below $400 \mathrm{~cm}^{-1}$ ), no peaks related to pure $\mathrm{K}_{0.5} \mathrm{Na}_{0.5} \mathrm{NbO}_{3}$ ceramics were highlighted. In the frequency range between 3500 and $1600 \mathrm{~cm}^{-1}$, instead, weak and broad peaks were recorded, while the broad absorbance peak of oxalic acid present in the proximity of $3300 \mathrm{~cm}^{-1}$ belongs to $\mathrm{O}-\mathrm{H}$ stretching from $\mathrm{H}_{2} \mathrm{O}$ contained in oxalic acid complex. The peaks detected in the frequency range $1500-1200 \mathrm{~cm}^{-1}$ could arise from combinations of absorbance due to organic functional groups, i.e. asymmetric or symmetric bending of $\mathrm{CH}_{3}$ groups, but could also be related to inorganic carbonates or bicarbonates $\left(\mathrm{HCO}_{3}^{-}\right.$) present in the gel [18] [19]. Since both $\mathrm{K}_{2} \mathrm{CO}_{3}$ and $\mathrm{Na}_{2} \mathrm{CO}_{3}$ spectra show a very strong absorbance in this frequency range, the origin of these peaks could also arise from the presence of an inorganic carbonate group [20]. The peak at $\sim 1425 \mathrm{~cm}^{-1}$ showed that hydrated carbonate phases persisted in the $\mathrm{K}_{0.5} \mathrm{Na}_{0.5} \mathrm{NbO}_{3}$ nanopowder sample even after decomposition at $600^{\circ} \mathrm{C}$.

It is probable that some of the hydrated carbonates detected in the FTIR spectrum are a consequence of a reaction between the $\mathrm{K}_{0.5} \mathrm{Na}_{0.5} \mathrm{NbO}_{3}$ nanopowders, after thermal decomposition, and moisture and carbon dioxide present in the air during the sample storage prior to making the FTIR analysis. It was also found that the spectrum recorded in the frequency range $800-500 \mathrm{~cm}^{-1}$ (see the inset of Figure 5) is not very different from those of pure $\mathrm{KNbO}_{3}$ and $\mathrm{NaNaO}_{3}$ [21] [22].

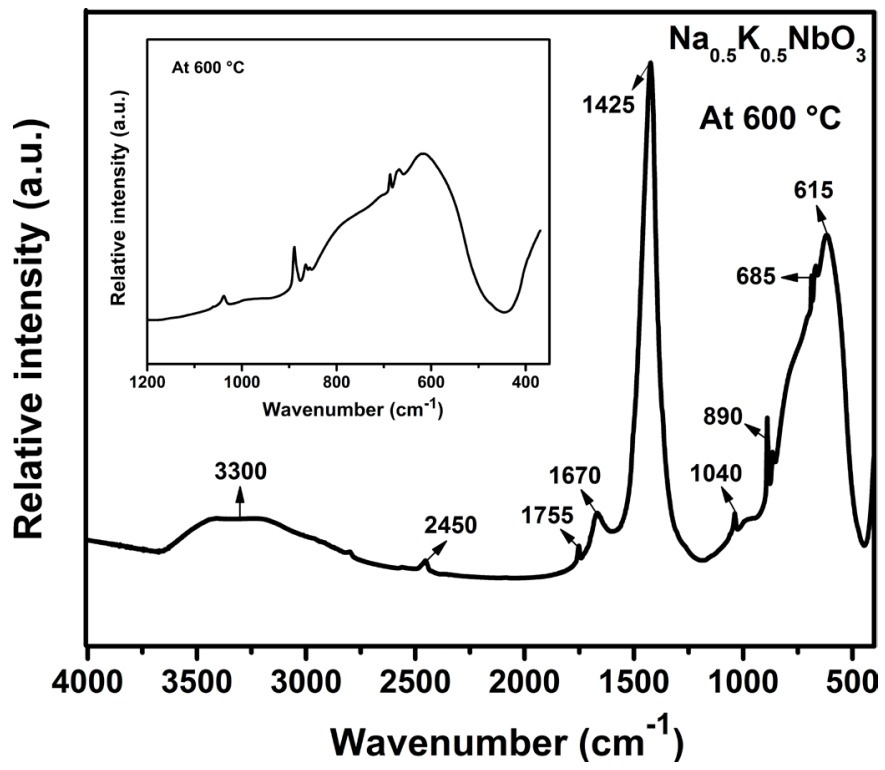

Figure 5. Fourier transform infrared spectrum of KNN gel-powder calcined at $600^{\circ} \mathrm{C}$. The inset shows a zoom of the spectrum in the range $1200-400 \mathrm{~cm}^{-1}$. 


\subsection{Williamson-Hall Analysis}

Figure 6 shows the Williamson-Hall plot of the $\mathrm{K}_{0.5} \mathrm{Na}_{0.5} \mathrm{NbO}_{3}$ nano-powder calcined at $600^{\circ} \mathrm{C}$. The Williamson-Hall analysis relies on the principle that the approximate formulae for the size broadening, $\beta_{L}$, and the strain broadening, $\beta_{e}$, vary quite differently with respect to the Bragg angle $\theta$ :

$$
\begin{gathered}
\beta_{L}=K \lambda / D \cos \theta \\
\beta_{e}=C \varepsilon \tan \theta
\end{gathered}
$$

where $K=0.94$ is the Scherrer's constant, $\lambda$ is the $X$-ray wavelength used $\mathrm{CuK}_{\alpha}=$ $1.5405 \AA, D$ is the average crystallite size, $\theta$ is the diffraction angle, $C$ is a constant depending on the strain (typically $\sim 4$ or 5 ) and $\varepsilon$ is the stored strain within alloy systems.

One contribution varies as $1 / \cos \theta$, while the other as $\tan \theta$. If both contributions are present, their combined effects should be convoluted to get the total broadening $\beta_{\mathrm{tot}}$. The simplification of Williamson and Hall is to assume the convolution as a simple sum of $\beta_{L}$ and $\beta_{e}$ :

$$
\beta_{\mathrm{tot}}=\beta_{e}+\beta_{L}=C \varepsilon \tan \theta+K \lambda / D \cos \theta
$$

Then multiplying both sides of Equation (5) by $\cos \theta$ we get:

$$
\beta_{\text {tot }} \cos \theta=C \varepsilon \sin \theta+K \lambda / D
$$

By plotting $\beta_{\mathrm{tot}} \cos \theta$ vs. $\sin \theta$, as illustrated in Figure 6 , and comparing the Equation (6) to the standard equation for a straight line $y=m x+c \quad(m=$ slope; $c=$ intercept), the strain component can be obtained from the slope $C \varepsilon$ [23]. A lattice strain of about $-0.32 \%$ has been determined; the negative value proves that the strain is compressive, while the low value indicates the occurrence of lattice relaxation within the $\mathrm{K}_{0.5} \mathrm{Na}_{0.5} \mathrm{NbO}_{3}$ nanocrystalline ceramic.

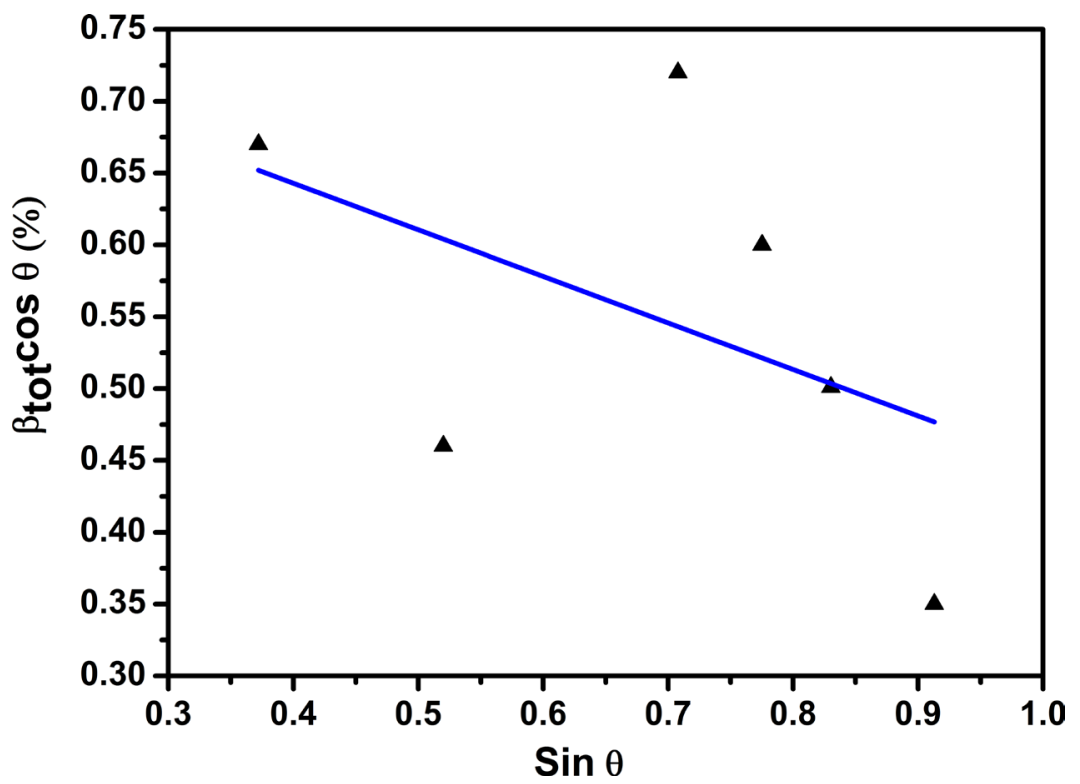

Figure 6. Williamson-Hall plot of KNN nanocrystalline powder calcined at $600^{\circ} \mathrm{C}$. The symbols are the experimental data, while the continuous blue line represents the linear fitting curve. 


\section{Conclusions}

High-quality $\mathrm{K}_{0.5} \mathrm{Na}_{0.5} \mathrm{NbO}_{3}$ nanocrystalline powders were prepared by a facile sol-gel technique, in which $\mathrm{Nb}_{2} \mathrm{O}_{5}$ was changed into a water-soluble species through the chemical chelation and was employed as the $\mathrm{Nb}$ source. $\mathrm{K}_{0.5} \mathrm{Na}_{0.5} \mathrm{NbO}_{3}$ gel prepared using citric acid solution was found to be homogenous, thus confirming the uniform mixing of $\mathrm{Nb}^{5+}, \mathrm{Na}$ and $\mathrm{K}$. Moreover, the gel precursor and the low processing temperature played a key role in the formation of the nanoparticles. The nanocrystalline $\mathrm{K}_{0.5} \mathrm{Na}_{0.5} \mathrm{NbO}_{3}$ powders prepared at a temperature as high as $400^{\circ} \mathrm{C}$ exhibited well-developed crystallinity and good morphology. In addition, the mean particle size of less than $50 \mathrm{~nm}$ shows the potential for the production of the low-temperature sintering-densified $\mathrm{K}_{0.5} \mathrm{Na}_{0.5} \mathrm{NbO}_{3}$ bulk material. Finally, a negative and low value of the lattice strain $(-0.32 \%)$ indicates the presence of a compressive strain and the occurrence of lattice relaxation in the synthesized KNN nanocrystalline ceramic. The modified low cost sol-gel method presented in this work ensured a high purity level of the fabricated KNN nanopowder and thus can be a milestone for the synthesis of other niobate solutions.

\section{Acknowledgements}

The authors acknowledge Dr. Angelica Chiodoni (CSHR, IIT, Torino, Italy) for FESEM measurements and Dr. Gian Paolo Salvador (CSHR, IIT, Torino, Italy) for FTIR and TGA/DSC measurements.

\section{References}

[1] Gao, R., Chu, X., Huan, Y., Wang, X. and Li, L. (2014) (K, Na) $\mathrm{NbO}_{3}$ Based Piezoceramics Prepared by a Two-Step Calcining and Ball Milling Route. Materials Letters, 123, 242-245.

[2] Goh, P.C., Yao, K. and Chen, Z. (2010) Lead-Free Piezoelectric $\left(\mathrm{K}_{0.5} \mathrm{Na}_{0.5}\right) \mathrm{NbO}_{3}$ Thin Films Derived from Chemical Solution Modified with Stabilizing Agents. Applied Physics Letters, 97, Article ID: 102901. https://doi.org/10.1063/1.3488808

[3] Acker, J., Kungl, H., Schierholz, R., Wagner, S., Eichel, R.-A. and Hoffmann, M.J. (2014) Microstructure of Sodium-Potassium Niobate Ceramics Sintered under High Alkaline Vapor Pressure Atmosphere. Journal of the European Ceramic Society, 34, 4213-4221.

[4] Li, J.-F., Wang, K., Zhu, F.-Y., Cheng, L.-Q. and Yao, F.-Z. (2013) (K, Na) $\mathrm{NbO}_{3}$ Based Lead-Free Piezoceramics: Fundamental Aspects, Processing Technologies, and Remaining Challenges. Journal of the American Ceramic Society, 96, 36773696. https://doi.org/10.1111/jace.12715

[5] Vendrell, X., Raymond, O., Ochoa, D.A., García, J.E. and Mestres, L. (2015) Growth and Physical Properties of Highly Oriented La-Doped (K, Na) $\mathrm{NbO}_{3}$ Ferroelectric Thin Films. Thin Solid Films, 577, 35-41.

[6] Ma, Q., Xu, Q., Tsai, C.-L., Tietz, F. and Guillon, O. (2016) A Novel Sol-Gel Method for Large-Scale Production of Nanopowders: Preparation of $\mathrm{Li}_{1.5} \mathrm{Al}_{0.5} \mathrm{Ti}_{1.5}\left(\mathrm{PO}_{4}\right)_{3}$ as an Example. Journal of the American Ceramic Society, 99, 410-414.

https://doi.org/10.1111/jace.13997

[7] Parmar, K., Sharma, H., Sharma, S. and Negi, N.S. (2015) Synthesis and Properties of Lead Free Ferroelectric $\mathrm{Na}_{0.5} \mathrm{Bi}_{0.5} \mathrm{TiO}_{3}$ Ceramic at Different Sintering Tempera- 
ture. Materials Science Forum, 830-831, 620-623.

https://doi.org/10.4028/www.scientific.net/MSF.830-831.620

[8] Cernea, M., Andronescu, E., Radu, R., Fochi, F. and Galassi, C. (2010) Sol-Gel Synthesis and Characterization of $\mathrm{BaTiO}_{3}$-Doped $\left(\mathrm{Bi}_{0.5} \mathrm{Na}_{0.5}\right) \mathrm{TiO}_{3}$ Piezoelectric Ceramics. Journal of Alloys and Compounds, 490, 690-694.

[9] Cernea, M., Poli, G., Aldica, G.V., Berbecaru, C., Vasile, B.S. and Galassi, C. (2012) Preparation and Properties of Nanocrystalline BNT-BT ${ }_{x}$ Piezoelectric Ceramics by Sol-Gel and Spark Plasma Sintering. Current Applied Physics, 12, 1100-1105.

[10] Sakamoto, W., Mizutani, Y., Iizawa, N., Yogo, T., Hayashi, T. and Hirano, S. (2005) Processing and Properties of Ferroelectric $(\mathrm{Bi}, \mathrm{La})_{4}(\mathrm{Ti}, \mathrm{Ge})_{3} \mathrm{O}_{12}$ Thin Films by Chemical Solution Deposition. Journal of the European Ceramic Society, 25, 2305 2308.

[11] Sakamoto, W., Mizutani, Y., Iizawa, N., Yogo, T., Hayashi, T. and Hirano, S. (2006) Synthesis and Properties of Ferroelectric Si-Doped (Bi, Nd) ${ }_{4} \mathrm{Ti}_{3} \mathrm{O}_{12}$ Thin Films by Chemical Solution Deposition. Journal of Electroceramics, 17, 293-297. https://doi.org/10.1007/s10832-006-0456-2

[12] Czechowska, K., Psiuk, B., Wrzalik, R., Szade, J., Burdyl, M., Śliwa, A. and Stec, K. (2014) Preparation of $\mathrm{KNbO}_{3}$ Powders by Sol-Gel Method Using Water-Soluble Potassium and Niobium Compounds as Precursors. Glass Physics and Chemistry, 40, 88-92. https://doi.org/10.1134/S1087659614010064

[13] Wang, L.H., Yuan, D.R., Duan, X.L., Wang, X.Q. and Yu, F.P. (2007) Synthesis and Characterization of Fine Lithium Niobate Powders by Sol-Gel Method. Crystal Research and Technology, 42, 321-324. https://doi.org/10.1002/crat.200610822

[14] Wang, C., Hou, Y., Ge, H., Zhu, M., Wang, H. and Yan, H. (2008) Sol-Gel Synthesis and Characterization of Lead-Free LNKN Nanocrystalline Powder. Journal of Crystal Growth, 310, 4635-4639.

[15] Muller, M. and Dehand, J. (1971) Oxalato-niobates et-tantalates de sodium. I. Obtention, conditions d'existence et caracterisation des differents complexes. Bulletin de la Société Chimique de France, 8, 2837-2842.

[16] Marta, L., Zaharescu, M. and Macarovici, C.Gh. (1979) Thermal and Structural Investigation of Some Oxalato-Niobic Complexes. I. Potassium Tris(oxalato)niobate. Revue Roumaine de Chimie, 24, 1115-1122.

[17] Birks, L.S. and Friedman, H. (1946) Particle Size Determination from X-Ray Line Broadening. Journal of Applied Physics, 17, 687. https://doi.org/10.1063/1.1707771

[18] Rojac, T., Kosec, M., Šegedin, P., Malič, B. and Holc, J. (2006) The Formation of a Carbonato Complex during the Mechanochemical Treatment of a $\mathrm{Na}_{2} \mathrm{CO}_{3}-\mathrm{Nb}_{2} \mathrm{O}_{5}$ Mixture. Solid State Ionics, 177, 2987-2995.

[19] Busca, G. and Lorenzelli, V. (1982) Infrared Spectroscopic Identification of Species Arising from Reactive Adsorption of Carbon Oxides on Metal Oxide Surfaces. Materials Chemistr, 7, 89-126.

[20] Chowdhury, A., Bould, J., Zhang, Y., James, C. and Milne, S.J. (2010) NanoPowders of $\mathrm{Na}_{0.5} \mathrm{~K}_{0.5} \mathrm{NbO}_{3}$ Made by a Sol-Gel Method. Journal of Nanoparticle Research, 12, 209-215. https://doi.org/10.1007/s11051-009-9595-0

[21] Shamim, M.M. and Ishidate, T. (2000) Anomalous Mode Coupling and Phase Transition of $\mathrm{KNbO}_{3}$ under High Pressure. Solid State Communications, 113, 713 17.

[22] Wang, B. and Zhang, L. (1998) Size Effects on Structure and Raman Spectra of Ba$\mathrm{TiO}_{3}$ Thin Films. Physica Status Solidi $(A), 169$, 57-62.

https://doi.org/10.1002/(SICI)1521-396X(199809)169:1<57::AID-PSSA57>3.0.CO;2- 
[23] Rani, R. and Sharma, S. (2016) Preparation and Characterization of $\mathrm{SnO}_{2}$ Nanofibers via Electrospinning. Advances in Nanoparticles, 5, 53-59.

https://doi.org/10.4236/anp.2016.51006

Submit or recommend next manuscript to SCIRP and we will provide best service for you:

Accepting pre-submission inquiries through Email, Facebook, LinkedIn, Twitter, etc. A wide selection of journals (inclusive of 9 subjects, more than 200 journals)

Providing 24-hour high-quality service

User-friendly online submission system

Fair and swift peer-review system

Efficient typesetting and proofreading procedure

Display of the result of downloads and visits, as well as the number of cited articles Maximum dissemination of your research work

Submit your manuscript at: http://papersubmission.scirp.org/

Or contact msa@scirp.org 